\title{
Polish government getting the message on environment
}

\section{London}

ENVIRONMENTAL issues have provided much controversy in Poland in recent years - notably the continued emission of sulphur dioxide at a rate of over 4 million tonnes annually from coal-burning power stations. Now, in what will be seen by the government's opponents as an attempt to prevent radical political groups from making ground by exploiting 'green' issues, the government has established an Ecological Social Movement to coordinate the work of clubs, committees and individuals for the protection of the environment and cultural monuments.

The new movement, under the chairmanship of the president of the Polish Academy of Sciences, Professor Jan Kostrzewski, will formally be a "self-governing and independent body", working under the patronage of PRON, the Patriotic Committee for National Rebirth. PRON was set up by the government during the martial law period to channel the various initiatives launched by the outlawed Solidarity trade union.

During the past year the extra-legal movement Freedom and Peace has won considerable public sympathy by espousing 'green' issues. Freedom and Peace

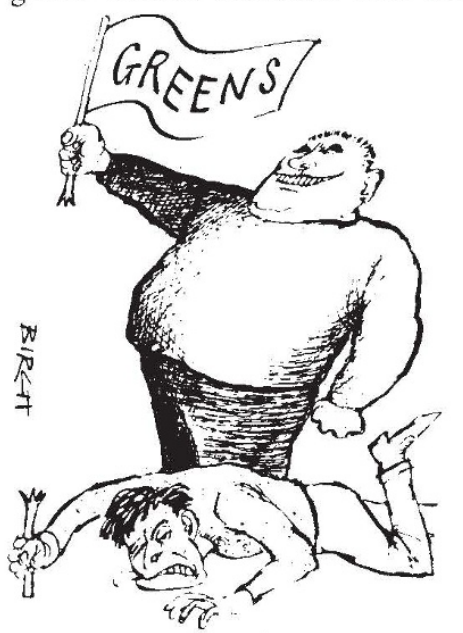

began as a campaign by young people against compulsory military service, objecting particularly to the military oath in which draftees express loyalty to the Soviet Union. Even the respectable Kraków Ecological Club has spoken up for the more radical Freedom and Peace group, suggesting that the Wroclaw city authorities should pay the fines imposed on those who took part in demonstrations against the Wroclaw steel mills

With its official links, the Ecological Social Movement will not be able to include the Freedom and Peace campaigners. But it would be simplistic to view the new body simply as a government ploy to 'hijack' the ecological movement. From a purely practical point of view, some central coordination of endeavours is necessary. Even one of the government's own programmes, that for environmental education in schools and universities, is being implemented unevenly and would benefit from better control, according to a recent study by Lublin Polytechnic. Another argument for a central body is that it may give more emphasis to the problems of the more remote areas, away from the large conurbations where pressure groups are more active. Perhaps the danger to Europe's last remaining tract of ancient forest, the Bialowieza, would have been more widely known if the new movement had been in existence earlier. The forest, straddling the Soviet - Polish border, may suffer irreparable harm when ground-water levels increase with the opening of the Siemionówka dam on the Narew river.

But a major reason for the foundation of the Ecological Social Movement may be a foreign policy move. A Polish Swedish cooperation programme on acid rain has been under discussion for some time and is at last taking shape. The Swedish negotiators, however, feel that progress would be much quicker if they were dealing with non-governmental organizations, rather than direct with government. The Swedes have suggested the Kraków Ecological Club as a suitable partner, but the new movement would provide a suitable organization operating at the national level.

\section{Field test of ice-minus bacteria goes ahead despite vandals}

\section{San Francisco}

AFTER a prolonged legal battle and a lastminute sabotage attempt, field tests of genetically engineered ice-minus bacteria have finally begun in California. Advanced Genetic Sciences (AGS) sprayed the bacteria, designed to protect plants from frost damage, on a strawberry patch in Contra Costa county at dawn on 24 April, the day after receiving the goahead from a Superior Court judge.

When the AGS scientists arrived at the site at 5 a.m., they found that vandals had slipped past two security guards, entered the fenced lot and uprooted 80 per cent of the stawberry plants. Most of the plants were intact, however, and once they had been replanted, Julie Lindemann, project leader, began applying the bacteria. Company officials said that the vandalism would not significantly disrupt the experiment

The project has suffered many legal delays. Plans for tests in Monterey County last year were blocked by local residents. Last spring the Environmental Protection Agency (EPA) suspended AGS's experimental permit and fined the company $\$ 13,000$ for conducting unapproved pathogenicity tests on fruit trees on the roof of their building. The EPA reinstated approval in September, and in February AGS chose the Contra Costa location. Contra Costa residents at first showed little concern, but opposition was raised by environmental groups from Berkeley and Monterey.

The test was approved by the California Department of Food and Agriculture (CDFA) on 13 April, but was delayed further by a suit filed by several environmental groups, including Jeremy Rifkin's Foundation on Economic Trends.
CDFA approval was based on hundreds of tests showing the bacteria will not spread to untreated plants and are not pathogenic to animals or to 47 different species of native and crop plants. The bacteria, which AGS plans to market under the trade name Frostban, are a mixture of two strains of Pseudomonas that lack the gene coding for an ice nucleation protein. They are classified as a pesticide because they minimize colonization of leaves and blossoms by iceforming Pseudomonas strains.

Lindemann applied the bacteria with a hand pump sprayer that produces large droplets, minimizing aerosol formation. She wore a protective suit and face mask required by the CDFA for testing of unregistered pesticides. Flats of barley plants in the 0.8 acres of barren buffer zone which surrounds the 0.2 acre strawberry patch will act as "traps" to monitor for the escape of bacteria, and air samplers will be used to check for airborn bacteria leaving the plot.

The goal of the field tests is to show whether Frostban can hold its own against naturally ouccurring bacteria and provide effective frost protection. During the six week experiment, researchers will take plants back to the laboratory to count bacteria, and will also measure the temperature at which the blossoms freeze. Unfortunately many blossoms were destroyed by the vandals, so some of the experiments will have to wait until after the second Frostban application in 10 days. Lindemann expects planty of new blossoms by then. Dozens more field tests will be necessary, before AGS can market the product, a goal they hope to realize in three years, said AGS vice president, John Bedbrook
Marcia Barinaga 